\title{
Innovative Techniques of Processing Human Milk to Preserve Key Components
}

\author{
Aleksandra Wesolowska ${ }^{1, * \mathbb{D}}$, Elena Sinkiewicz-Darol ${ }^{2}$, Olga Barbarska ${ }^{1}$, \\ Urszula Bernatowicz-Lojko ${ }^{2}$, Maria Katarzyna Borszewska-Kornacka ${ }^{3}$ and \\ Johannes B. van Goudoever 4
}

1 Laboratory of Human Milk and Lactation Research at Regional Human Milk Bank in Holy Hospital, Medical University of Warsaw, Department of Neonatology, 63A Zwirki i Wigury St., 02-091 Warsaw, Poland; olga.barbarska@wum.edu.pl

2 Human Milk Bank, Ludwik Rydygier' Provincial Polyclinical Hospital in Torun, Torun, 53-59 St. Jozef St., 87-100 Torun, Poland; elena.darol@wszz.torun.pl (E.S.-D.); ursber@interia.pl (U.B.-L.)

3 Department of Neonatology and Intensive Care Unit, 1st Faculty of Medicine, Medical University of Warsaw; Karowa 2, 00-315 Warsaw, Poland; maria.borszewskakornacka@gmail.com

4 Department of Pediatrics, Emma Children's Hospital, Amsterdam UMC, Vrije Universiteit Amsterdam, P.O. Box 7057, 1007 MB Amsterdam, The Netherlands; h.vangoudoever@amsterdamumc.nl

* Correspondence: aleksandra.wesolowska@wum.edu.pl; Tel./Fax: +48-22-317-9343

Received: 29 April 2019; Accepted: 20 May 2019; Published: 24 May 2019

\begin{abstract}
Human milk not only contains all nutritional elements that an infant requires, but is also the source of components whose regulatory role was confirmed by demonstrating health-related deficiencies in formula-fed children. A human milk diet is especially important for premature babies in the neonatal intensive care unit (NICU). In cases where breastfeeding is not possible and the mother's own milk is insufficient in volume, the most preferred food is pasteurized donor milk. The number of human milk banks has increased recently but their technical infrastructure is continuously developing. Heat treatment at a low temperature and long time, also known as holder pasteurization $\left(62.5^{\circ} \mathrm{C}, 30 \mathrm{~min}\right)$, is the most widespread method of human milk processing, whose effects on the quality of donor milk is well documented. Holder pasteurization destroys vegetative forms of bacteria and most viruses including human immunodeficiency virus (HIV) herpes and cytomegalovirus (CMV). The macronutrients remain relatively intact but various beneficial components are destroyed completely or compromised. Enzymes and immune cells are the most heat sensitive elements. The bactericidal capacity of heat-pasteurized milk is lower than that of untreated milk. The aim of the study was for a comprehensive comparison of currently tested methods of improving the preservation stage. Innovative techniques of milk processing should minimize the risk of milk-borne infections and preserve the bioactivity of this complex biological fluid better than the holder method. In the present paper, the most promising thermal pasteurization condition $\left(72{ }^{\circ} \mathrm{C}-75^{\circ} \mathrm{C}\right.$,) and a few non-thermal processes were discussed (high pressure processing, microwave irradiation). This narrative review presents an overview of methods of human milk preservation that have been explored to improve the safety and quality of donor milk.
\end{abstract}

Keywords: breastfeeding; high pressure processing; newborn; holder pasteurization; human milk; donor milk

\section{Introduction}

Recent findings have confirmed the therapeutic properties of human milk components and have left no doubt that it constitutes an indispensable part of newborns' nutritional treatment, especially premature babies with very low (VLBW) and extremely low (ELBW) birth weight. Initiating lactation in 
preterms' mothers and maintaining mother's milk supply for NICU infants remains challenging. Donor milk has become the standard way of feeding newborns who cannot receive the milk of their biological mothers [1]. Donor milk administration to prematurely born children needing longer hospital stays requires necessary collecting procedures, freezing, storage and pasteurization. This may considerably lower its nutritional and therapeutic values. So far, the best characterized and commonly used method of human milk preservation is holder pasteurization. However, the knowledge about the significant negative impacts of this method on the active components in human milk results in the development of novel techniques that could better preserve nutritional and non-nutritional factors.

The aim of this narrative review was to analyze the best characterized and current methods of human milk processing in the context of minimizing qualitative and quantitative losses of its bioactive elements and ensuring safety in clinical situations.

\section{Materials and Methods}

The literature review included electronic searches of MEDLINE (January 2000-January 2019), EMBASE (January 2000-January 2019) and conference proceedings. The electronic search used the following text words and MeSH terms: donor milk, human milk, breast milk, banked milk, (human milk OR donor milk) AND pasteurization [-] (human milk OR breast milk) AND, preservation (human milk OR breast milk) AND holder pasteurization (human milk OR breast milk) AND, high-pressure (human milk OR breast milk), UV-treatment (human milk OR breast milk), microwave (human milk OR breast milk). Reference lists of the previous reviews and relevant studies were examined. Research that had been reported only as abstracts were eligible for inclusion if sufficient information was available from the report.

\section{Results and Discussion}

Microbiological safety is the primary criterion that has to be fulfilled as far as food for newborns is concerned. Therefore, firstly we focus on the effectiveness of the proposed human milk processing methods in human milk pathogen elimination (Table 1).

Microbiota associated with human milk mostly reflects the mother's health status but contributes to both maternal and infant homeostasis [2]. Small amounts of bacteria from the nipple and the areola, such as Escherichia coli, Serratia marcescens, and Pseudomonas aeruginosa are often present in human milk. Moreover, due to milk flow back from the newborn's mouth cavity into the mammary ducts, Streptococcus sp. and Staphylococcus sp. are present in mother's milk in physiological conditions [3]. On the other hand, bacteria connected with mastitis, namely Staphylococcus aureus, Streptococcus agalacitiae and Corynebacterium, are potentially dangerous for newborns. Human milk may also become contaminated with other bacteria such as Listeria monocytogenes, Enterobacter cloacae and Klebsiella pneumoniae as a result of improper expressing, collection and storage [4]. Antibodies against numerous pathogenic bacteria, fungi and viruses are present in human milk and passed to the breastfed infant to prevent mother-to-child disease transmission. 
Table 1. Studies of Holder Pasteurization, High-Temperature Short-Time, High Pressure Processing and Microwave Irradiation HoP, HTST, HPP, MI on microbiological and viral components of human milk.

\begin{tabular}{|c|c|c|c|c|c|}
\hline Tested Component & HoP & HTST & HPP & MI & References \\
\hline Bacteriostatic effect on E.coli and L. iпnосиа & $\begin{array}{l}48 \% \text { reduction } \\
28 \% \text { reduction }\end{array}$ & $\begin{array}{l}64 \% \text { reduction } \\
39 \% \text { reduction }\end{array}$ & not studied & not studied & {$[5,6]$} \\
\hline $\begin{array}{l}\text { Inactivation of selected microorganisms (L. monocytogenes } S . \\
\text { agalactiae, E. coli, S. aureus) }\end{array}$ & inactivation & not studied & inactivation & not studied & [7] \\
\hline Inactivation of selected microorganisms (Enterobacteriaceae) & inactivation & not studied & inactivation & not studied & [8] \\
\hline $\begin{array}{c}\text { Inactivation of selected microorganisms (S. aureus ATCC } \\
6538, \text { Enterobacteriaceae) }\end{array}$ & not studied & not studied & inactivation & not studied & [9] \\
\hline $\begin{array}{l}\text { Antibacterial efficacy (Coagulase-negative staphylococci, } \\
\text { Gram- negative bacteria, Enterococcus species) }\end{array}$ & reduced bacterial counts & reduced bacterial counts & not studied & not studied & [10] \\
\hline $\begin{array}{l}\text { Microbiological quality (vegetative forms of } \\
\text { microorganisms present in raw milk samples) }\end{array}$ & $\begin{array}{l}\text { destroyed commensal and } \\
\text { contaminant vegetative } \\
\text { microorganisms except Bacillus } \\
\text { sp. }\end{array}$ & $\begin{array}{l}\text { destroyed all vegetative forms } \\
\text { of microorganisms except } \\
\text { Bacillus sp. and E. faecalis }\end{array}$ & not studied & not studied & [11] \\
\hline Inactivation of selected microorganisms (S.aureus) & inactivation & not studied & inactivation & not studied & [12] \\
\hline Inactivation of selected microorganisms (S.aureus, B. cerues) & partial inactivation & not studied & inactivation & not studied & [13] \\
\hline $\begin{array}{c}\text { Inactivation of selected microorganisms (E.coli, P. aeruginosa, } \\
\text { S. aureus, S. epidermidis) }\end{array}$ & inactivation & not studied & not studied & inactivation & {$[14]$} \\
\hline Ebola Virus & inactivation & not studied & not studied & not studied & [15] \\
\hline Marburg Virus & inactivation & not studied & not studied & not studied & [15] \\
\hline Zika virus & inactivation & not studied & not studied & not studied & [16] \\
\hline CMV & $\begin{array}{l}\text { Inactivation } \\
\text { destroy viral infectivity }\end{array}$ & destroy viral infectivity & not studied & inactivation & [17-19] \\
\hline $\begin{array}{c}\text { HTLV } \\
\text { HIV }\end{array}$ & inactivation & inactivation & not studied & not studied & [20] \\
\hline HPV high-risk (types 16 and 18), low-risk (type 6) & inactivation & not studied & not studied & not studied & [21] \\
\hline
\end{tabular}


Due to this fact, even though the milk of an infected mother does contain pathogens, bioactive components of the natural food effectively prevent the entry of bacteria and viruses into the digestive tract of a child. Free fatty acids and monoglycerides (products of triglycerides lipolysis) found in human milk exhibit anti-fungal activity [22]. The bacteriostatic properties of human milk depend on its specific antibodies but also result from toxin neutralization by cellular components of the immune system, as well as bacterial translocation blocking by intestinal mucosa. Therefore, the binding of Streptococcus pneumoniae and Escherichia coli to their proper receptors is inhibited by human milk oligosaccharides (HMO) and in the case of Campylobacter jejuni, by fucosyl oligosaccharides. Kappa-casein is a specific ligand for Helicobacter pylori. Neutralization of Escherichia coli, Clostridium difficile, Salmonella enterica and Shigella enterotoxins is the reason why breastfeeding successfully protects against bacterial diarrhea [23]. Also, the binding of rotaviruses by stable sedimentation of $46 \mathrm{kDa}$ glycoprotein (lactadherin), resulting in the alleviation of infectious symptoms, has been confirmed [24]. Therefore, with proper hygiene during the process of expressing and storage conditions, bacterial infections of infants caused by the milk of their mothers are extremely rare. Donor milk that is intended for a child other than a biological child undergoes more restrictive handling [25]. Human milk may also be a source of cytomegalovirus (CMV), hepatitis B virus (HBV) and human T lymphotropic retrovirus (HTLV I and II), as well as HIV 1, 2 infection. Even though transmission through human milk is rare, the pasteurization parameters of milk intended for children should ensure the deactivation of pathogenic viruses HIV, HTLV, CMV, rubella virus and herpes virus (HCV) (hepatitis virus is relatively heat-resistant) [26].

\subsection{Methods of Human Milk Processing}

Low temperature long time (LTLT) pasteurization, also known as the holder method (HoP), is considered to be the standard for human milk pasteurization. Milk is incubated for 30 min at $62.5^{\circ} \mathrm{C}$ in a water bath or other device that ensures effective heating $[27,28]$. Modern milk pasteurizers guarantee precise measurement of the temperature inside the bottle, automatic control of the process and the possibility of efficient and safe milk cooling to low temperature (usually $4{ }^{\circ} \mathrm{C}$ ) [29]. Other methods of high temperature pasteurization at $72-75^{\circ} \mathrm{C}$, the so-called HTST (high temperature short time (HTST) or FHP flash-heat pasteurization (FHP), are used to effectively eliminate microorganisms [30,31]. Flash pasteurization applies especially in countries with a high risk of HIV infection. It was adopted as a simple, universally accessible method and does not require any sophisticated equipment. Today a simple, portable, low resource piece of equipment for FHP is available on the market. Escuder-Vieco and coworkers [11] recently demonstrated an HTST equipment for the continuous processing of human milk that could be adopted in milk banks. International research has shown that the high temperature short time method was effective in eradicating HIV, Escherichia coli, Staphylococcus aureus and Streptococcus $A$ and $B$, while protecting the nutritional composition of human milk including important vitamins [32-34]. Also, investigations of methods combining thermal processing with homogenization techniques, for example ultrasound, are being carried out at present. Other physical factors such as UV, microwaves, electric pulses, and high pressures as alternatives to the traditional thermal process of inactivating microorganisms in human milk have been tested [35-41].

One of the most promising non-thermal method is high pressure processing (HPP), which is becoming a more and more popular method of food preservation on an industrial scale. It seems to be more efficient in achieving microbial purity of human milk, while still preserving its maximal therapeutic value $[7,42,43]$.

\subsection{Temperature and High Pressure Influence on Microbial Purity of Human Milk}

The main goal of human milk pasteurization is to remove pathogens that might possibly be the cause of an infection when donor milk is given to an infant as an alternative to formula feeding (in accordance with WHO, UNICEF and AAP guidelines) [1,44]. The efficiency of pathogen elimination such as Mycobacterium tuberculosis by heating milk to $62.5^{\circ} \mathrm{C}$ was first checked in cow's milk [28]. Later research confirmed the possibility of removing vegetative forms of numerous types of bacteria present 
in human milk as well as the risk that endosporic forms and toxins will survive, like in the case of Bacillus cereus, still remain [45]. This is why in many European countries, the microbial purity of human milk is controlled twice, before and after pasteurization, eliminating milk with a level of Staphyloccocus aureus above $10^{4} \mathrm{CFU}$ (colony forming units) before pasteurization and/or an overall bacteria count above $10^{5} \mathrm{CFU}$. In the absence of a unified acceptance criteria for milk before pasteurization with respect to microbial purity, in order for milk to be given to someone other than the biological child of the donor, vegetative forms of bacteria must be eliminated (Table 1).

In the case of Ebola virus, Marburg and Zika viruses, inactivation happens only by using thermal processing (HoP). So far, there is no data on whether HTST or HPP are equally effective as HoP in eliminating these viruses $[15,16]$.

HTST pasteurization $\left(72{ }^{\circ} \mathrm{C}, 5-16 \mathrm{~s}\right)$ seems to be more effective than the holder method in eliminating bacteria and viruses with lipid envelopes (HIV, HTLV), as well as model viruses for HCV and hepatitis B virus that cannot be otherwise deactivated [20,46]. Even high temperatures do not completely eliminate viruses without lipid envelopes like Parvovirus B19, but apart from experimental conditions, no risk of infection transferred through human milk has been reported [31]. HTST was reported to efficiently destroy $\mathrm{CMV}$ infectivity in a process at $72{ }^{\circ} \mathrm{C}$ for $5 \mathrm{~s}$ [17]. Microwave radiation at high-power settings has proved to inactivate CMV in human milk as well [19] (Table 1).

Recently, Escuder-Vieco reported that HTST processing at $72{ }^{\circ} \mathrm{C}$ for at least $10 \mathrm{~s}$ efficiently destroyed all vegetative forms of microorganisms present in raw milk [11]. However, sporulated Bacillus sp. survived this thermal process. In earlier studies Klotz and coworkers did not find a difference in the reduction of naturally present microorganisms in raw milk after HTST in comparison to HoP treatment [10]. High pressure processing (HPP) is becoming an increasingly popular method for food preservation on an industrial scale. The selective effects of high pressures allows the conditions (pressure, temperature, presence of water) to be chosen, in order to selectively destroy pathogenic cells and preserve more of the valuable human milk components. HPP is a successful method of eliminating Gram-positive and Gram-negative bacteria, though vegetative cells are more effectively destroyed than endosporic forms. The destruction of Listeria monocytogenes, Eschericha coli, Staphylococcus aureus, Staphylococcus agalactiae and Salmonella spp. within the pressure range of 300-400 MPa has been proved safe for a lot of milk proteins with active hormones and enzymes. Viruses such as HIV and CMV are also deactivated $[7,31,43]$. HPP was shown to be even more effective in comparison to holder pasteurization in the elimination of inoculated microbiological flora (total viable count microorganisms, S. aureus) of raw milk [12]. A recent study showed that high pressure processing can be an effective method of eliminating bacteria which produce spores, like Bacillus cereus [13]. Foods pasteurized by means of the HPP method are freer of microbes than products of thermal processing. Therefore, HPP may possibly be used in the future in milk banks, providing nutrition for newborns with special dietary needs.

\subsection{The Influence of Processing on Bioactive Components of Human Milk}

The effects of different types of processing (HoP, HTST, HPP) on human milk bioactive factors are shown in Table 2. Methodology discrepancies between included research papers, especially in biological factors given as an indicator of milk bioactivity, did not allow for a systematic review of the topic. This is a main limitation of our study. 
Table 2. Effects of different type of processing (Holder Pasteurization, High-Temperature Short-Time, High Pressure Processing and Microwave Irradiation) on human milk factors.

\begin{tabular}{|c|c|c|c|c|c|}
\hline \multirow[t]{2}{*}{ Factor } & НоР & HTST & $\begin{array}{c}\text { HPP } \\
400-600 \mathrm{MPa} \\
5-30 \mathrm{~min}, 12^{\circ} \mathrm{C} 37^{\circ} \mathrm{C}\end{array}$ & MI & References \\
\hline & Activity Loss/Reduce of Concentration & $\begin{array}{l}\text { Activity Loss/Reduce of } \\
\text { Concentration }\end{array}$ & Activity Loss/Reduce of Concentration & $\begin{array}{l}\text { Activity Loss/Reduce of } \\
\text { CONCENTRATION }\end{array}$ & \\
\hline \multirow{5}{*}{ Lactoferrin } & $\begin{array}{l}63-100 \% \\
44-80 \%\end{array}$ & & * decrease (600 MPa $15 \mathrm{~min})$ & & \\
\hline & $64-83 \%$ & $11 \%$ & $21-44 \%(200+400-600 \mathrm{MPa}, 10 \mathrm{~min})$ & & \\
\hline & $\begin{array}{l}80 \% \\
60 \%\end{array}$ & $\begin{array}{c}68 \% \\
0-14 \%\end{array}$ & $\begin{array}{l}300 \mathrm{MPa}-650 \mathrm{MPa} 15 \mathrm{~min}, 20^{\circ} \mathrm{C} \\
300,400,500,600 \mathrm{MPa}, 15 \mathrm{~min}, 20^{\circ} \mathrm{C}\end{array}$ & ns & {$[5,6,10,12,13,27,30,31,33,47-52]$} \\
\hline & $39 \%$ & $71 \%$ & $9-48 \%$ & & \\
\hline & $\begin{array}{c}61 \% \\
80^{\circ}\left({ }^{\circ}{ }^{\circ} \mathrm{C}\right)\end{array}$ & & $3-7 \%$ & & \\
\hline \multirow{4}{*}{ Lysozyme } & $\begin{array}{l}* \text { decrease } 21-67 \% \text { (reduction } \\
\text { concentration) }\end{array}$ & & & & \\
\hline & $\begin{array}{l}\text { concentration) } \\
33-76 \%\end{array}$ & & $\begin{array}{c}107 \% \\
400 \mathrm{MPa} 30 \mathrm{~min}\end{array}$ & & \\
\hline & $\begin{array}{l}35 \% \\
* * 1 \text { increas }\end{array}$ & $\begin{array}{c}55 \% \\
28 \% * \text { increase }\end{array}$ & $\begin{array}{l}400 \mathrm{MPa} 30 \mathrm{~min} \\
14-25 \%\end{array}$ & * decrease & {$[5-7,10,13,28,30,33,39,53]$} \\
\hline & $\begin{array}{l}{ }^{*} \text { increase } \\
\text { stable }\end{array}$ & & & & \\
\hline Antioxidant activity (glutathione, glutathione & $\begin{array}{c}48 \% \\
* \text { decrease in glutathione concentration }\end{array}$ & & & SOD and GPx activity & \\
\hline $\begin{array}{l}\text { peroxidase, malonedialdehyde, superoxide } \\
\text { dismutase, TAC) }\end{array}$ & $\begin{array}{l}\text { (about 50\%), GPx activity (near 67\%) and } \\
\text { TAC (about } 58 \% \text { ) reduced GPX }\end{array}$ & Decrease & $\begin{array}{l}\text { no significant changes in TAC, reduction of AsA }>11 \%(200 \\
\left.\qquad \mathrm{MPa}^{-2}-20^{\circ} \mathrm{C}\right)\end{array}$ & $\begin{array}{l}\text { temporary increased during } \\
\text { microwave heating }\end{array}$ & {$[41,53-55]$} \\
\hline Oligosaccharides & $\begin{array}{l}\text { IAC (about } \\
\text { stable }\end{array}$ & Stable & ns & ns & {$[33,56,57]$} \\
\hline Biogenic amines & stable & Ns & ns & ns & {$[58]$} \\
\hline Glucocorticoids (cortisol, cortisone) & not significantly affected & & & & [59] \\
\hline $\begin{array}{l}\text { Adiponectin } \\
\text { HMV Adiponectin }\end{array}$ & $34 \%$ & Ns & $62-98 \%$ & ns & {$[12,60]$} \\
\hline $\begin{array}{l}\text { HMV Adiponectin } \\
\text { Insulin }\end{array}$ & $46 \%$ & $\mathrm{Ns}$ & $5-18 \%$ & $n s$ & {$[1260]$} \\
\hline & $33 \%$ & & & & \\
\hline Leptin & $\begin{array}{c}40 \%\left(57^{\circ} \mathrm{C}, 30 \mathrm{~min}\right) \\
78 \%\end{array}$ & Ns & $48-90 \%$ (* increase in leptin concentration) & ns & {$[12,61]$} \\
\hline Medium-chain saturated fatty acids & no change in content & Ns & no change in content & ns & {$[62,63]$} \\
\hline Long-chain unsaturated fatty acids & $\begin{array}{l}\text { no change in content, slight decrease of } \\
\text { oleic acid content }\end{array}$ & Ns & no change in content & ns & {$[62,63]$} \\
\hline $\begin{array}{c}\text { Polyunsaturated fatty acids } n=3, n=6 \text { Linolenic } \\
\text { acid }\end{array}$ & no change in content & Ns & no change in content & ns & [62-65] \\
\hline Folic acid & $36 \%$ & $*$ increase & ns & ns & [66]; \\
\hline Vitamin A & $\begin{array}{l}\text { Stable decrease from } 55.5 \mathrm{mg} / 100 \mathrm{~mL} \text { to } \\
36.6 \mathrm{mg} / 100 \mathrm{~mL} \text {, about } 34 \%\end{array}$ & Stable & ns & ns & [66-68] \\
\hline Vitamin B1(thiamine) & ns & $\begin{array}{l}\text { Stable } \\
\text { stable }\end{array}$ & ns & ns & [27] \\
\hline Vitamin B2 & stable & $\begin{array}{l}\text { staole } \\
41 \% \\
59 \%\end{array}$ & ns & ns & {$[27,66,67]$} \\
\hline & & & & & \\
\hline Vitamin B6 & $15 \%$ & $\begin{array}{l}18 \% \\
59 \%\end{array}$ & ns & ns & {$[27,66]$} \\
\hline Vitamin B12 & $48 \%$ & increase & ns & ns & {$[66,69]$} \\
\hline Vitamin C & $\begin{array}{c}36 \% \\
16 \% \\
20-36 \% \\
35 \%\end{array}$ & $\begin{array}{c}\text { stable } \\
* \text { increase }\end{array}$ & $\begin{array}{c}\text { no change } \\
<5 \% \\
\left(2000 \mathrm{MPa},-20^{\circ} \mathrm{C}\right)\end{array}$ & ns & {$[27,41,63,66]$} \\
\hline Vitamin D & stable & Ns & ns & ns & {$[67]$} \\
\hline Vitamin E (tocopherol) & stable & Ns & ns & ns & {$[63,67]$} \\
\hline Lysine & higher content of available lysine & Stable & ns & ns & [50] \\
\hline
\end{tabular}


Table 2. Cont

\begin{tabular}{|c|c|c|c|c|c|}
\hline Factor & HoP & HTST & $\begin{array}{c}\text { HPP } \\
400-600 \mathrm{MPa} \\
5-30 \mathrm{~min}, 12^{\circ} \mathrm{C} 37^{\circ} \mathrm{C}\end{array}$ & MI & References \\
\hline & Activity Loss/Reduce of Concentration & $\begin{array}{l}\text { Activity Loss/Reduce of } \\
\text { Concentration }\end{array}$ & Activity Loss/Reduce of Concentration & $\begin{array}{l}\text { Activity Loss/Reduce of } \\
\text { CONCENTRATION }\end{array}$ & \\
\hline $\operatorname{IgM}$ & $\begin{array}{c}\text { complete deactivation } \\
\text { decrease in content }\end{array}$ & Ns & ns & ns & {$[47,70]$} \\
\hline $\operatorname{IgA}$ & $\begin{array}{c}20-100 \% \\
27 \% \\
21.1 \% \\
\text { decrease in content } \\
57 \%\left(65{ }^{\circ} \mathrm{C}\right) \\
98 \% \\
49 \% \\
56 \%\end{array}$ & $\begin{array}{c}20 \% \\
5 \% \\
74,8 \% \\
57 \%\end{array}$ & $\begin{array}{c}0 \%(400 \mathrm{mPa}) \\
13 \%(500 \mathrm{MPa}) \\
32 \%(600 \mathrm{mPa}) \\
5 \mathrm{~min} 12^{\circ} \mathrm{C} \\
40 \% \\
400,500,600 \mathrm{MPa} \\
5 \mathrm{~min}, 12{ }^{\circ} \mathrm{C} \\
0-31 \% \\
17 \%\end{array}$ & no significant effect & {$[8,10,13,33,39,43,50-52,70]$} \\
\hline $\operatorname{Ig} G$ & $\begin{array}{l}\text { 34-100\% } \\
\text { decrease in content } \\
49 \%\end{array}$ & $33 \%$ & $18-70 \%$ & ns & {$[12,47,70]$} \\
\hline Alkaline phosphatase & complete loss & $94 \%$ & ns & ns & [10] \\
\hline Lipoprotein Lipase & $\begin{array}{l}\text { complete loss } \\
99 \%\end{array}$ & $\begin{array}{l}\text { stable } \\
99 \%\end{array}$ & $\begin{array}{c}15-20 \% \\
\text { stable }\end{array}$ & & {$[10,13,50,65]$} \\
\hline Lactoperoxidase & $50-88 \%$ & stable & ns & ns & [49] \\
\hline Amylase & $15 \%$ & ns & ns & ns & [65] \\
\hline Mannose-binding lectin & stable & ns & ns & ns & [71] \\
\hline CD 14 (soluble) & $88 \%$ & ns & ns & ns & [71] \\
\hline TGF $\beta 1$ TGF $\beta 1$ & decrease $<1 \%$ & ns & stable & ns & [72-74] \\
\hline TGF $\alpha$ & $\begin{array}{l}\text { decrease }<6 \% \\
\text { stable }\end{array}$ & ns & ns & ns & {$[70,72,73]$} \\
\hline IL-10 & ${ }^{*}$ decrease in content & substantial decrease & $\begin{array}{c}\text { decrease }\left(400 \mathrm{MPa}, 5 \mathrm{~min}, 12^{\circ} \mathrm{C}\right) \\
{ }^{*} \text { decrease }(500 \mathrm{MPa}) \\
\text { no presence at } 600 \mathrm{MPa}\end{array}$ & ns & {$[33,62,73,74]$} \\
\hline Erythropoietin & decrease & ns & ns & ns & [73] \\
\hline IFN- & decrease in content & ns & ns & ns & [62] \\
\hline TNF- $\alpha$ & ${ }^{*}$ decrease in content & ns & $\begin{array}{c}\text { decrease }(400 \mathrm{MPa}), \\
* \text { decrease }(500 \mathrm{MPa}, 600 \mathrm{MPa})\end{array}$ & ns & {$[62,74]$} \\
\hline TNF-RI & increase in content & ns & $\begin{array}{c}\text { increase }(400 \mathrm{MPa}) \text {, increase }(500 \mathrm{MPa}), \\
\quad{ }^{*} \text { increase }(600 \mathrm{MPa})\end{array}$ & ns & [74] \\
\hline
\end{tabular}


Table 2. Cont.

\begin{tabular}{|c|c|c|c|c|c|}
\hline Factor & HoP & HTST & $\begin{array}{c}\text { HPP } \\
400-600 \mathrm{MPa} \\
5-30 \mathrm{~min}, 12{ }^{\circ} \mathrm{C} 37^{\circ} \mathrm{C}\end{array}$ & MI & References \\
\hline & Activity Loss/Reduce of Concentration & $\begin{array}{l}\text { Activity Loss/Reduce of } \\
\text { Concentration }\end{array}$ & Activity Loss/Reduce of Concentration & $\begin{array}{l}\text { Activity Loss/Reduce of } \\
\text { CONCENTRATION }\end{array}$ & \\
\hline IL-1 $\alpha$ & $\begin{array}{l}{ }^{*} \text { decrease in content } \\
\text { substantial decrease }\end{array}$ & ns & ns & ns & [62] \\
\hline IL-2 & decrease in content & ns & ns & ns & [62] \\
\hline IL-4 & decrease in content & ns & ns & ns & [62] \\
\hline IL-5 & decrease in content & ns & ns & ns & [62] \\
\hline IL-12p70 & decrease in content & ns & ns & ns & [62] \\
\hline IL-13 & *decrease in content & ns & $\begin{array}{l}\text { increase }(400 \mathrm{MPa}), \\
{ }^{*} \text { decrease }(500 \mathrm{MPa}) \\
{ }^{*} \text { decline }(600 \mathrm{MPa})\end{array}$ & ns & {$[62,74]$} \\
\hline IL-8 & $\begin{array}{l}25 \% \text { increased content } \\
{ }^{*} \text { increase of activity } \\
* \text { increase }\end{array}$ & $\begin{array}{l}\text { not studied } \\
{ }^{*} \text { increase }\end{array}$ & $\begin{array}{l}\text { increase }(400 \mathrm{MPa}), \\
{ }^{*} \text { increase }(500 \mathrm{MPa}) \\
* \text { increase }(600 \mathrm{MPa})\end{array}$ & ns & {$[33,62,74]$} \\
\hline IL-6 & ${ }^{*}$ decrease of activity & ns & increase (400 MPa, $500 \mathrm{MPa}, 600 \mathrm{MPa}$ ) & ns & [74] \\
\hline HGF & $\begin{array}{l}33 \% \\
89 \%\end{array}$ & ns & $3-66 \%$ & ns & {$[12,62]$} \\
\hline EGF & $\begin{array}{l}0910 \\
\text { stable }\end{array}$ & stable & stable & ns & [18] \\
\hline IGF-1 & $39 \%$ & stable & ns & ns & [18] \\
\hline IGF-2 & $9.9 \%$ & stable & ns & ns & [18] \\
\hline IGF-BP2 & $19.1 \%$ & stable & ns & ns & [18] \\
\hline IGF-BP3 & $7 \%$ & stable & ns & ns & [18] \\
\hline $\begin{array}{l}\text { Free nucleotide monophosphates (AMP, GMP, } \\
\text { CMP, TMP) }\end{array}$ & stable & ns & $\begin{array}{l}\text { 400, 500, } 600 \mathrm{MPa} 5 \text { min (without temp. control) stable or } \\
\text { increased content }\end{array}$ & ns & [75] \\
\hline Volatile profile & $\begin{array}{l}\text { modified the volatile profile (lipid } \\
\text { oxidation, Maillard reaction) }\end{array}$ & ns & $\begin{array}{l}\text { HPP at } 400 \text { or } 600 \text { MPa for } 3 \text { min preserved the original } \\
\text { volatile compounds of human milk }\end{array}$ & ns & [76] \\
\hline
\end{tabular}


Table 2. Cont.

\begin{tabular}{|c|c|c|c|c|c|}
\hline \multicolumn{6}{|c|}{ High Pressure Thermal Processing } \\
\hline $\begin{array}{l}\text { Fatty acids, cytokines, leukocytes and } \\
\text { immunoglobulins (IgM, IgA and IgG) }\end{array}$ & ns & ns & $\begin{array}{l}300-900 \mathrm{MPa} \text {, temp. } 50-80{ }^{\circ} \mathrm{C} \text {, for } 1 \mathrm{~min} \\
\text { minimal effect on the levels of IL-12, IL-17 and IFN- } \gamma \text {. loss } \\
\text { of leukocytes cells, only the treatments at } 300 \mathrm{MPa} \text { and } 50 \\
\text { of } \mathrm{C} \text { maintained certain levels of Igs (IgM } 25 \% \text { loss, IgA } 52 \% \\
\text { and IgG } 0 \% \text { ) }\end{array}$ & ns & [77] \\
\hline \multirow[t]{2}{*}{ Factor } & HoP & HTST & $\begin{array}{c}\mathrm{HPP} \\
400-600 \mathrm{MPa} \\
5-30 \mathrm{~min}, 12^{\circ} \mathrm{C} 37^{\circ} \mathrm{C} \\
\end{array}$ & MI & References \\
\hline & activity loss/reduce of concentration & $\begin{array}{l}\text { activity loss/reduce of } \\
\text { concentration }\end{array}$ & activity loss/reduce of concentration & $\begin{array}{l}\text { activity loss/reduce of } \\
\text { concentration }\end{array}$ & \\
\hline $\begin{array}{l}\text { Tocopherols, fatty acids, cytokines (IL-6, IL-8, } \\
\text { IL-10, IL-12 (p70), IL-17, IFN- } \gamma \text {, TNF- } \alpha \text { and } \\
\text { MCAF/MCP-1) }\end{array}$ & $\begin{array}{l}\text { * decreased the levels of } \alpha \text {-, } \gamma \text {-and } \\
\delta \text {-tocopherol }\end{array}$ & ns & $\begin{array}{l}600 \mathrm{MPa} \text { * decreased the levels of } \alpha \text {-, } \gamma \text { - and } \delta \text {-tocopherol, } \\
\text { reduction proportions of some key fatty acids, not affect on } \\
\text { the levels of IL- } 6 \text {, IL- } 8 \text { and TNF- } \alpha \text {. }\end{array}$ & ns & [78] \\
\hline IgA, IgM, IgG, & $\begin{array}{l}\text { IgA 20\% } \\
\text { IgM } 51 \% \\
\text { IgG 23\% }\end{array}$ & ns & $\begin{array}{l}\text { no/small effect on Igs, } \\
\text { stable }\end{array}$ & ns & [42] \\
\hline volatile profile & ns & ns & $\begin{array}{l}300-900 \mathrm{MPa}, 50-80^{\circ} \mathrm{C} \\
\text { * modified volatile profile }\end{array}$ & ns & [76] \\
\hline
\end{tabular}

HoP-Holder Pasteurization, HTST-High-Temperature Short-Time, HPP-High Pressure Processing, MI-Microwave Irradiation, MPa-Megapascal, GPx-glutathione peroxidase, TAC-total
antioxidant capacity, AsA-ascorbic acid, SOD-superoxide dismutase, HMV-high molecular weight, IgA-immunoglobulin A, IgM-immunoglobulin M, IgG-immunoglobulin G, CD 14-cluster of differentiation 14, TGF $\beta_{1}$-transforming growth factor beta 1, TGF $\beta_{2}$-transforming growth factor beta 2, TGF $\alpha$-transforming growth factor alpha, IL10-interleukin 10, IFN- $\gamma$-interferon gamma, TNF $\alpha$-tumor necrosis factor alpha, TNF-RI-tumor necrosis factor receptor, IL-1 $\alpha$-interleukin 1 alpha, IL-2-interleukin 2, IL-4-interleukin 4, IL-5-interleukin 5 , IL-12p70-interleukin 12, IL-13-interleukin 13, IL-8-interleukin 8, IL-6-interleukin 6, IL 17-interleukin 17, HGF-hepatocyte growth factor, EGF-epidermal Growth Factor, IGF1-insulin-like growth factor, IGF2-insulin-like growth factor 2, IGF-BP2-insulin like growth factor binding protein 2, IGF-BP3-insulin like growth factor binding protein 3, AMP-adenosine monophosphate, GMP-guanosine monophosphate, CMP-cytidine monophosphate, TMP-thymidine monophosphate, MCAF/MCP-1-monocyte chemotactic and activating factor/monocyte chemoattractant protein-1,* statistically significant $(p<0,05)$, ns-not studied. 
The bacteriostatic effect of human milk, resulting from the presence of lysozyme, lactoferrin and lactoperoxidase, is an extremely valuable property. The first experiments conducted to preserve human milk by Wills revealed a reduction in lactoferrin and lysozyme activity after holder pasteurization to $27 \%$ and $67 \%$, respectively [28]. Other investigations demonstrated lactoferrin activity was completely destroyed and a changing effect on the lysozyme, depending on the experimental conditions [6]. The latest research showed a reduced content and activity of lysozyme, lactoperoxidase and lactoferrin, while a shorter incubation time in higher temperature $\left(75^{\circ} \mathrm{C}, 15 \mathrm{~s}\right.$ versus $\left.62.5^{\circ} \mathrm{C}, 30 \mathrm{~min}\right)$ proved to have better results as far as antibacterial properties were concerned [30]. Moreover, recent studies have shown a $40 \%$ reduction of lactoferrin concentration in HoP-treated milk [12]. This could explain the several-fold increase of bacteria in milk after pasteurization in comparison to fresh or frozen milk [49]. Taking both methods of thermal processing into consideration, longer incubation at lower temperatures ( $62.5^{\circ} \mathrm{C}, 30 \mathrm{~min}$.) appears to be more suitable. It is due to this fact that, in comparison to HTST which reduces the bacteriostatic effect of milk to $36 \%$, holder pasteurization preserves $52 \%$ of bactericidal properties (as controls non-pasteurized milk caused a $70 \%$ reduction in E. coli growth). Subsequent storage at $4{ }^{\circ} \mathrm{C}$ for 48 and $72 \mathrm{~h}$ did not affect the bactericidal effect, which had been confirmed by earlier investigations [5].

Tests of the effect on Listeria innocua antigens, measured with ELISA, confirmed the superiority of holder pasteurization. The bacteriostatic effect was 1.8 units in non-pasteurized milk, 1.3 activity units ( $28 \%$ decrease in activity) in milk pasteurized by LTLT, and 1.1 units ( $39 \%$ decrease) by HTLT [48]. It is difficult to compare the effect of HTST on the concentration and activity of lysozymes and enzymes with bacterial activity. Peila and coworkers pointed out that the results are divergent due to different methods that were used for HTST in each study [79]. Measurements of antioxidant levels in pasteurized milk showed reduced antioxidant activity in human milk in high temperatures. It is important to mention that shorter incubation at higher temperatures $\left(75^{\circ} \mathrm{C} 15 \mathrm{~s}\right)$ caused a smaller loss of human milk components that neutralize free radicals [54].

Bertino demonstrated no changes in oligosaccharide composition after holder pasteurization, therefore donor milk may be a source of these valuable biomolecules [56]. Temperatures within the range of $62.5-63{ }^{\circ} \mathrm{C}$ do not influence the presence of gangliosides, the receptors for Bifidobacteria adhesion proteins [62]. What is more, the process does not change the amount of biogenic polyamines, like spermine and spermidine, and their regulatory functions [58].

Thermal processing depletes human milk of hormones such as adiponectin, insulin and leptin. In a study by Ley et al. the reduction of adiponectin and insulin was $33 \%$ and $46 \%$, respectively [60]. Another study showed a reduction of HMV adiponectin, insulin and leptin concentration of $38 \%, 32 \%$ and $88 \%$ respectively, and also incubation at $57^{\circ} \mathrm{C}$ reduced the number of bioactive peptides like leptin $[12,61]$. In contrast to temperature treatment, in four tested variants of high pressure: $600 \mathrm{MPa}$, $100+600 \mathrm{MPa}, 200+400 \mathrm{MPa}$ and $200+600 \mathrm{MPa}$ the reduction in HPP content was $64 \%, 61 \%, 2 \%$ and $57 \%$, respectively. Adipokines, key metabolism regulation components (leptin, insulin, HMV adiponectin) of infant growth and body composition, have also been targeted in studies. Compared to the thermal method, HPP lead to better retention of leptin and insulin. In the case of leptin, high pressure processing even caused an increase in concentration (148-186\%) [12].

Holder pasteurization seems to have no significant influence on the overall content of fats in milk, leaving the activity of unsaturated LC-PUFA fatty acids like DHA and AA unaltered [64,65]. High pressures also do not deactivate free fatty acids, only at high pressure combined with high temperature (600-900 MPa $50{ }^{\circ} \mathrm{C}-80^{\circ} \mathrm{C}$ ) were changes in the proportion of some fatty acids observed [62,63,77,78]. However, the latest research indicated a 5.5\% decrease in the overall content of lipids before and after pasteurization, and the content of the analyzed components differed significantly between the samples [80]. It is important to have in mind that the absence of lipase, which hydrolyzes fatty acids in non-pasteurized milk releasing them from triacylglycerols, may also influence the obtained values of fatty acid levels in pasteurized milk. That explains, reported in some studies, the slightly elevated level of these fats in pasteurized milk [65]. The analysis of lactose isomerization markers and Maillard 
reaction markers showed that lactulose and furosine concentrations were lower in HTST-treated milk than after holder pasteurization. In this study, $\gamma$-glutamil transpeptidase was also shown to be thermoresistant, but both methods completely destroyed alkaline phosphatase [11]. In most studies, ALP and lipases activity are completely reduced by both thermal methods [10]. So far, only one study showed higher concentrations of bile salt-stimulated lipase (BSSL) and total lipase activity in milk treated with HTST in comparison with HoP [50]. High hydrostatic pressure is also effective in preserving BSSL, the retention of lipase in milk samples after using the HPP method was 80-85\% [13].

Earlier research demonstrated that holder pasteurization at $62.5{ }^{\circ} \mathrm{C}$ does not influence the content of vitamins A, D, E, B2 in human milk and vitamin B12 is reduced to $48 \%$ in comparison to non-pasteurized milk $[67,69]$. Folic acid, vitamins B1, B2, B6 and C seem to be resistant to the influence of even higher temperatures (up to $72^{\circ} \mathrm{C}$ ) [27]. Later research demonstrates vitamin A content decreases in milk after holder pasteurization and, consequently, its deficiency in pasteurized milk $(36.6+/-26.1$ $\mathrm{mg} / 100 \mathrm{~mL})$ [68]. Holder pasteurization reduces the amount of vitamin C (36\%), folic acid (31\%) and vitamin B6 $(15 \%)$ in human milk $[27,63]$. The higher temperature $\left(75^{\circ} \mathrm{C}\right)$ used for HIV deactivation in human milk also lowers the concentration of vitamin B6 (92\%) and B2 (59\%), without influencing vitamin A. At the same time, high temperature processing increases the effect of vitamin C, B12 and folic acid [66]. Regardless of the processing method, active alpha-, gamma- and delta- tocopherols are preserved in human milk, in contrast to vitamin $C$ which, as the latest studies proved, is reduced by at least $16 \%$ in high temperatures. Compared to thermal processing, HPP had no significant effect on the content of vitamin C and E $[63,77]$. A study by Vieira and coworkers indicated that human milk processed within the temperature range of $62-62.5^{\circ} \mathrm{C}$ has a significant impact on the overall content of proteins (a median decrease of protein content in pasteurized versus non-pasteurized milk of 4\%) [80]. HTST pasteurization appears to have less influence on the activity of individual proteins in human milk, which was confirmed by proteomic studies [50]. Among various classes of antibodies present in human milk, IgA are relatively stable, whereas IgG are deprived of a large part of their activity and IgM are completely deactivated after both HoP and HTST pasteurization [47,69]. At first, Goldbloom et al. showed that HTST had no significant effect on IgA [47], but a later study presented that $5 \mathrm{~s}$ at $72{ }^{\circ} \mathrm{C}$ resulted in loss of IgA similar to this after HoP [27]. The use of HPP resulted in a $36 \%$ decrease in IgA content in milk samples [13]. Recent studies have shown that HoP had a statistically significant effect on IgG (49\% reduction) and that retention of this immunoglobulin after HPP was in the range of $30 \%$ to $82 \%$, depending on the high pressure applied [12]. Bile salt-stimulated lipase (BSSL) and other enzymes such as lactoperoxidase and amylase are also deactivated by temperature $[49,50,65]$. Immunological cells present in milk are destroyed and the amount of other components influencing host defense mechanisms, for example the soluble form of the CD14 antigen, is lowered, with an unaffected number of mannose-binding lectins [71,80].

Numerous growth factors present in fresh human milk remain active also after holder pasteurization, for example EGF (epidermal growth factor) or TGF $\beta$ and TGF $\alpha$ (transforming growth factor) $[18,72]$. Unfortunately, holder pasteurization significantly deactivates proteins such as IL-10, erythropoietin, IFN- $\gamma$, TNF- $\alpha$, IL-1, IL-6, IL-13, HGF [73]. Wesolowska has recently reported that compared to holder pasteurization (89\% reduction), HPP led to a better retention of HGF [12]. Cytokines from the group of insulin-like growth factors, IGF-1 and IGF-2, and their binding proteins, IGF-BP 2 and 3 , are destroyed in the process of long incubation at $62^{\circ} \mathrm{C}$, while short pasteurization at high temperatures does not affect them $\left(72^{\circ} \mathrm{C}, 5 \mathrm{~s}\right)$ [18].

High pressure processing appears to be the most effective in preserving protein activity. The protective effect of high pressures depends on the presence of hydrogen bonds and secondary structure of proteins (structure of beta-sheet is more pressure-resistant than alpha helix). Protein denaturation below $400 \mathrm{MPa}$ is a reversible process due to the effect of high pressure on the weakest hydrogen bonds and Van der Waals force, while preserving the integrity of covalent bonds and the structure ensuring enzymatic activity. The selective effect of high pressures allows the conditions (pressure, temperature, presence of water) to be chosen in order to selectively destroy pathogenic cells and preserve more of 
the valuable components of human milk. It was confirmed by results regarding the stability of a large group of relatively heat-resistant cytokines (EGF, TGF- $\beta 2$, TNF-RI, TGF- $\beta 1$ and IL- 8 ) at $400 \mathrm{MPa}$, as well as statistically significant in the activity of temperature-sensitive cytokines in milk processed at high pressures, (IL-6, IL-13, TNF- $\alpha$ and IL-10, HGF), and high pressure processing of human milk also allows, to a greater extent, the activity of IgA antibodies to be preserved. Within the range of 400 to $600 \mathrm{MPa}$ and at a temperature of $12{ }^{\circ} \mathrm{C}$, the effect of IgA alters slightly (activity decreases to $88 \%$ for $500 \mathrm{MPa}$ and $69 \%$ for $600 \mathrm{MPa}$ ). At $400 \mathrm{MPa}$, the activity of IgA in human milk remains intact in comparison to a $72 \%$ decrease in traditionally pasteurized milk $\left(62.5^{\circ} \mathrm{C}, 30 \mathrm{~min}\right)$. The use of $350 \mathrm{MPa}$ pressure at $38{ }^{\circ} \mathrm{C}$ in certain conditions led to a $36 \%$ reduction in the content of IgA [13]. Also, the activity of lysozyme is unaffected by high pressures or thermal processing $[8,13,43]$.

\section{Conclusions}

Mother's own fresh expressed milk is an extremely valuable source of components with both nutrient and bioactive activities, such as bacteriostatic factors, oligosaccharides, vitamins and growth factors. The combined effect of the nutritional and bioactive components decides on the short-term and long-term health benefits of a human milk-based diet in the preterm newborn population. Some of the latest research has shown a partial activity of human milk after holder pasteurization for important biological implications such as anti-infective properties, immune components, microbiota and growth factors $[79,81,82]$.

Improvement of the techniques allowing the preservation of the bioactivity of donor milk is profitable in the context of the health effects related to child feeding choice. Proven and safe techniques adopted from the food industry have created opportunities to minimize losses as a consequence of human milk processing. The new methods applied to human milk should be at least as effective as the old ones to ensure microbiological safety.

Data evaluating the effectiveness of interventions with thermal pasteurized donor milk are not clear [83-87], and there are no clinical trials concerning new techniques. Therefore, studies with human participants are needed to be carried out with the most promising new techniques of human milk processing in comparison to holder pasteurization.

It is essential to bear in mind if there is a real possibility of introducing new equipment into the market and its usage in routine milk bank services [88].

Author Contributions: Conceptualization, A.W.; U.B.-L.; M.K.B.-K.; methodology A.W., formal analysis, E.S.-D.; investigation, A.W., E.S.-D.; resources, A.W.; data curation, A.W.; E.S.-D.; writing-original draft preparation, A.W.; writing—review and editing, E.S.-D.; O.B. visualization, A.W.; E.S.-D.; O.B.; supervision, M.K.B.-K.; J.B.v.G.; project administration, A.W.; funding acquisition, A.W.

Funding: Supported by the grant of Polish Ministry of Science and Higher Education "Incubator of Innovation Plus".

Conflicts of Interest: The authors declare no conflict of interest.

\section{References}

1. WHO; UNICEF. Global Strategy for Infant and Young Child Feeding; World Health Organization: Geneva, Switzerland, 2003.

2. Ojo-Okunola, A.; Nicol, M.; du Toit, E. Human Breast Milk Bacteriome in Health and Disease. Nutrients 2018, 10, 1643. [CrossRef] [PubMed]

3. Rodríguez, J.M. The origin of human milk bacteria: Is there a bacterial entero-mammary pathway during late pregnancy and lactation? Adv. Nutr. 2014, 5, 779-784. [CrossRef] [PubMed]

4. Shetty, A.; Barnes, R.; Adappa, R.; Doherty, C. Quality control of expressed breast milk. J. Hosp. Infect. 2006, 62, 253-254. [CrossRef] [PubMed]

5. Silvestre, D.; Ruiz, P.; Martinez-Costa, C.; Plaza, A.; Lopez, M. Effect of pasteurization on the bactericidal capacity of human milk. J. Hum. Lact. 2008, 24, 371-376. [CrossRef] [PubMed] 
6. Czank, C.; Prime, D.K.; Hartmann, B.; Simmer, K.; Hartmann, P.E. Retention of the immunological proteins of pasteurized human milk in relation to pasteurizer design and practice. Pediatric Res. 2009, 66, 374. [CrossRef] [PubMed]

7. Viazis, S.; Farkas, B.; Jaykus, L. Inactivation of bacterial pathogens in human milk by high-pressure processing. J. Food Prot. 2008, 71, 109-118. [CrossRef] [PubMed]

8. Permanyer, M.; Castellote, C.; Ramírez-Santana, C.; Audí, C.; Pérez-Cano, F.; Castell, M.; López-Sabater, M.; Franch, A. Maintenance of breast milk immunoglobulin A after high-pressure processing. J. Dairy Sci. 2010, 93, 877-883. [CrossRef] [PubMed]

9. Windyga, B.; Rutkowska, M.; Sokołowska, B.; Skapska, S.; Wesołowska, A.; Wilińska, M.; Fonberg-Broczek, M.; Rzoska, S.J. Inactivation of Staphylococcus aureus and native microflora in human milk by high pressure processing. High Press. Res. 2015, 35, 181-188. [CrossRef]

10. Klotz, D.; Joellenbeck, M.; Winkler, K.; Kunze, M.; Huzly, D.; Hentschel, R. High-temperature short-time pasteurisation of human breastmilk is efficient in retaining protein and reducing the bacterial count. Acta Paediatr. 2017, 106, 763-767. [CrossRef]

11. Escuder-Vieco, D.; Espinosa-Martos, I.; Rodriguez, J.M.; Corzo, N.; Montilla, A.; Siegfried, P.; Pallás-Alonso, C.R.; Fernández, L. High-Temperature Short-Time pasteurization system for donor milk in a human milk bank setting. Front. Microbiol. 2018, 9, 926. [CrossRef]

12. Wesolowska, A.M.; Sinkiewicz-Darol, E.; Barbarska, O.; Strom, K.; Rutkowska, M.; Karzeł, K.; Rosiak, E.; Olędzka, G.; Orczyk-Pawiłowicz, M.; Rzoska, S.J. New achievements in high-pressure processing to preserve human milk bioactivity. Front. Pediatrics 2018, 6, 323. [CrossRef]

13. Demazeau, G.; Plumecocq, A.; Lehours, P.; Martin, P.; Couëdelo, L.; Billeaud, C. A new high hydrostatic pressure process to assure the microbial safety of human milk while preserving the biological activity of its main components. Front. Public Health 2018, 6, 306. [CrossRef]

14. Malinowska-Pańczyk, E.; Królik, K.; Skorupska, K.; Puta, M.; Martysiak-Żurowska, D.; Kiełbratowska, B. Microwave heat treatment application to pasteurization of human milk. Innov. Food Sci. Emerg. Technol. 2019, 52, 42-48. [CrossRef]

15. Hamilton Spence, E.; Huff, M.; Shattuck, K.; Vickers, A.; Yun, N.; Paessler, S. Ebola virus and Marburg virus in human milk are inactivated by Holder pasteurization. J. Hum. Lact. 2017, 33, 351-354. [CrossRef] [PubMed]

16. Pfaender, S.; Vielle, N.J.; Ebert, N.; Steinmann, E.; Alves, M.P.; Thiel, V. Inactivation of Zika virus in human breast milk by prolonged storage or pasteurization. Virus Res. 2017, 228, 58-60. [CrossRef] [PubMed]

17. Hamprecht, K.; Maschmann, J.; Müller, D.; Dietz, K.; Besenthal, I.; Goelz, R.; Middeldorp, J.M.; Speer, C.P.; Jahn, G. Cytomegalovirus (CMV) inactivation in breast milk: Reassessment of pasteurization and freeze-thawing. Pediatric Res. 2004, 56, 529. [CrossRef]

18. Goelz, R.; Hihn, E.; Hamprecht, K.; Dietz, K.; Jahn, G.; Poets, C.; Elmlinger, M. Effects of different CMV-heat-inactivation-methods on growth factors in human breast milk. Pediatric Res. 2009, 65, 458. [CrossRef]

19. Ben-Shoshan, M.; Mandel, D.; Lubetzky, R.; Dollberg, S.; Mimouni, F.B. Eradication of cytomegalovirus from human milk by microwave irradiation: A pilot study. Breastfeed. Med. 2016, 11, 186-187. [CrossRef] [PubMed]

20. Yamamoto, K.; Taguchi, H.; Yoshimoto, S.; Fujishita, M.; Yamashita, M.; Ohtsuki, Y.; Hoshino, H.; Miyoshi, I. Inactivation of lymphocyte-transforming activity of human T-cell leukemia virus type I by heat. Jpn. J. Cancer Res. Gann 1986, 77, 13-15.

21. Donalisio, M.; Cagno, V.; Vallino, M.; Moro, G.E.; Arslanoglu, S.; Tonetto, P.; Bertino, E.; Lembo, D. Inactivation of high-risk human papillomaviruses by Holder pasteurization: Implications for donor human milk banking. J. Perinat. Med. 2014, 42, 1-8. [CrossRef]

22. Hamosh, M. Protective function of proteins and lipids in human milk. Neonatology 1998, 74, $163-176$. [CrossRef]

23. Morrow, A.L.; Ruiz-Palacios, G.M.; Altaye, M.; Jiang, X.; Guerrero, M.L.; Meinzen-Derr, J.K.; Farkas, T.; Chaturvedi, P.; Pickering, L.K.; Newburg, D.S. Human milk oligosaccharides are associated with protection against diarrhea in breast-fed infants. J. Pediatrics 2004, 145, 297-303. [CrossRef] 
24. Newburg, D.S.; Peterson, J.A.; Ruiz-Palacios, G.M.; Matson, D.O.; Morrow, A.L.; Shults, J.; de Lourdes Guerrero, M.; Chaturvedi, P.; Newburg, S.O.; Scallan, C.D. Role of human-milk lactadherin in protectoin against symptomatic rotavirus infection. Lancet 1998, 351, 1160-1164. [CrossRef]

25. Eglash, A.; Simon, L.; Medicine, A.O.B. ABM clinical protocol\# 8: Human milk storage information for home use for full-term infants, Revised 2017. Breastfeed. Med. 2017, 12, 390-395.

26. Lanari, M.; Sogno Valin, P.; Natale, F.; Capretti, M.; Serra, L. Human milk, a concrete risk for infection? J. Matern.-Fetal Neonatal Med. 2012, 25, 67-69. [CrossRef] [PubMed]

27. Goldblum, R.M.; Dill, C.W.; Albrecht, T.B.; Alford, E.S.; Garza, C.; Goldman, A.S. Rapid high-temperature treatment of human milk. J. Pediatrics 1984, 104, 380-385. [CrossRef]

28. Wills, M.; Han, V.; Harris, D.; Baum, J. Short-time low-temperature pasteurisation of human milk. Early Hum. Dev. 1982, 7, 71-80. [CrossRef]

29. Buffin, R.; Pradat, P.; Trompette, J.; Ndiaye, I.; Basson, E.; Jordan, I.; Picaud, J.-C. Air and water processes do not produce the same high-quality pasteurization of donor human milk. J. Hum. Lact. 2017, 33, 717-724. [CrossRef]

30. Chantry, C.J.; Wiedeman, J.; Buehring, G.; Peerson, J.M.; Hayfron, K.; K'Aluoch, O.; Lonnerdal, B.; Israel-Ballard, K.; Coutsoudis, A.; Abrams, B. Effect of flash-heat treatment on antimicrobial activity of breastmilk. Breastfeed. Med. 2011, 6, 111-116. [CrossRef] [PubMed]

31. Terpstra, F.G.; Rechtman, D.J.; Lee, M.L.; Hoeij, K.V.; Berg, H.; Engelenberg, F.A.V.; Wout, A.B.V.t. Antimicrobial and antiviral effect of high-temperature short-time (HTST) pasteurization applied to human milk. Breastfeed. Med. 2007, 2, 27-33. [CrossRef] [PubMed]

32. Chaudhri, R.; Vlachos, D.; Kaza, J.; Palludan, J.; Bilbao, N.; Martin, T.; Borriello, G.; Kolko, B.; Israel-Ballard, K. A system for safe flash-heat pasteurization of human breast milk. In Proceedings of the 5th ACM Workshop on Networked Systems for Developing Regions, Bethesda, MD, USA, 28 June 2011; pp. 9-14.

33. Daniels, B.; Schmidt, S.; King, T.; Israel-Ballard, K.; Amundson Mansen, K.; Coutsoudis, A. The Effect of Simulated Flash-Heat Pasteurization on Immune Components of Human Milk. Nutrients 2017, 9, 178. [CrossRef]

34. Naicker, M.; Coutsoudis, A.; Israel-Ballard, K.; Chaudhri, R.; Perin, N.; Mlisana, K. Demonstrating the efficacy of the FoneAstra pasteurization monitor for human milk pasteurization in resource-limited settings. Breastfeed. Med. 2015, 10, 107-112. [CrossRef]

35. Christen, L.; Lai, C.T.; Hartmann, B.; Hartmann, P.E.; Geddes, D.T. The effect of UV-C pasteurization on bacteriostatic properties and immunological proteins of donor human milk. PLoS ONE 2013, 8, e85867. [CrossRef] [PubMed]

36. Christen, L.; Lai, C.T.; Hartmann, B.; Hartmann, P.E.; Geddes, D.T. Ultraviolet-C irradiation: A novel pasteurization method for donor human milk. PLoS ONE 2013, 8, e68120. [CrossRef] [PubMed]

37. Ferreira, C.S.; Amato Neto, V.; Gakiyai, E.; Bezerra, R.C.; Rodríguez Alarcón, R.S. Microwave treatment of human milk to prevent transmission of Chagas disease. Rev. Inst. Med. Trop. São Paulo 2003, 45, 41-42. [CrossRef]

38. Ovesen, L.; Jakobsen, J.; Leth, T.; Reinholdt, J. The effect of microwave heating on vitamins $\mathrm{B}_{1}$ and E, and linoleic and linolenic acids, and immunoglobulins in human milk. Int. J. Food Sci. Nutr. 1996, 47, 427-436. [CrossRef]

39. Quan, R.; Yang, C.; Rubinstein, S.; Lewiston, N.J.; Sunshine, P.; Stevenson, D.K.; Kerner, J.A. Effects of microwave radiation on anti-infective factors in human milk. Pediatrics 1992, 89, 667-669.

40. Martysiak-Żurowska, D.; Puta, M.; Kotarska, J.; Cybula, K.; Malinowska-Pańczyk, E.; Kołodziejska, I. The effect of UV-C irradiation on lipids and selected biologically active compounds in human milk. Int. Dairy J. 2017, 66, 42-48. [CrossRef]

41. Martysiak-Żurowska, D.; Puta, M.; Barczak, N.; Dąbrowska, J.; Malinowska-Pańczyk, E.; Kiełbratowska, B.; Kołodziejska, I. Effect of high pressure and sub-zero temperature on total antioxidant capacity and the content of vitamin C, fatty acids and secondary products of lipid oxidation in human milk. Pol. J. Food Nutr. Sci. 2017, 67, 117-122. [CrossRef]

42. Sousa, S.G.; Delgadillo, I.; Saraiva, J.A. Effect of thermal pasteurisation and high-pressure processing on immunoglobulin content and lysozyme and lactoperoxidase activity in human colostrum. Food Chem. 2014, 151, 79-85. [CrossRef] 
43. Viazis, S.; Farkas, B.E.; Allen, J.C. Effects of high-pressure processing on immunoglobulin A and lysozyme activity in human milk. J. Hum. Lact. 2007, 23, 253-261. [CrossRef]

44. Johnston, M.; Landers, S.; Noble, L.; Szucs, K.; Viehmann, L. American Academy of Pediatrics, Section on Breastfeeding, Policy Statement: Breastfeeding and the use of human milk. Pediatrics 2012, 129, e827-e841. [CrossRef]

45. Landers, S.; Updegrove, K. Bacteriological screening of donor human milk before and after Holder pasteurization. Breastfeed. Med. 2010, 5, 117-121. [CrossRef] [PubMed]

46. Orloff, S.L.; Wallingford, J.; McDougal, J. Inactivation of human immunodeficiency virus type I in human milk: Effects of intrinsic factors in human milk and of pasteurization. J. Hum. Lact. 1993, 9, 13-17. [CrossRef]

47. Goldsmith, S.J.; Dickson, J.S.; Barnhart, H.M.; Toledo, R.T.; Eiten-Miller, R.R. IgA, IgG, IgM and lactoferrin contents of human milk during early lactation and the effect of processing and storage. J. Food Prot. 1983, 46, 4-7. [CrossRef] [PubMed]

48. Chen, H.-Y.; Allen, J.C. Human Milk Antibacterial Factors. In Bioactive Components of Human Milk; Springer: Boston, MA, USA, 2001; pp. 341-348.

49. Akinbi, H.; Meinzen-Derr, J.; Auer, C.; Ma, Y.; Pullum, D.; Kusano, R.; Reszka, K.J.; Zimmerly, K. Alterations in the host defense properties of human milk following prolonged storage or pasteurization. J. Pediatric Gastroenterol. Nutr. 2010, 51, 347-352. [CrossRef]

50. Baro, C.; Giribaldi, M.; Arslanoglu, S.; Giuffrida, M.G.; Dellavalle, G.; Conti, A.; Tonetto, P.; Biasini, A.; Coscia, A.; Fabris, C. Effect of two pasteurization methods on the protein content of human milk. Front. Biosci. 2011, 3, 818-829. [CrossRef]

51. Mayayo, C.; Montserrat, M.; Ramos, S.; Martínez-Lorenzo, M.; Calvo, M.; Sánchez, L.; Pérez, M. Kinetic parameters for high-pressure-induced denaturation of lactoferrin in human milk. Int. Dairy J. 2014, 39, 246-252. [CrossRef]

52. Parrón, J.A.; Ripollés, D.; Ramos, S.J.; Pérez, M.D.; Semen, Z.; Rubio, P.; Calvo, M.; Sánchez, L. Antirotaviral potential of lactoferrin from different origin: Effect of thermal and high pressure treatments. BioMetals 2018, 31, 343-355. [CrossRef]

53. Guerra, A.F.; Mellinger-Silva, C.; Rosenthal, A.; Luchese, R.H. Hot topic: Holder pasteurization of human milk affects some bioactive proteins. J. Dairy Sci. 2018, 101, 2814-2818. [CrossRef]

54. Silvestre, D.; Miranda, M.; Muriach, M.; Almansa, I.; Jareno, E.; Romero, F.J. Antioxidant capacity of human milk: Effect of thermal conditions for the pasteurization. Acta Paediatr. 2008, 97, 1070-1074. [CrossRef] [PubMed]

55. Martysiak-Żurowska, D.; Puta, M.; Kiełbratowska, B. The effect of convective heating and microwave heating on antioxidant enzymes in pooled mature human milk. Int. Dairy J. 2019, 91, 41-47. [CrossRef]

56. Bertino, E.; Coppa, G.; Giuliani, F.; Coscia, A.; Gabrielli, O.; Sabatino, G.; Sgarrella, M.; Testa, T.; Zampini, L.; Fabris, C. Effects of Holder pasteurization on human milk oligosaccharides. Int. J. Immunopathol. Pharmacol. 2008, 21, 381-385. [CrossRef]

57. Hahn, W.-h.; Kim, J.; Song, S.; Park, S.; Kang, N.M. The human milk oligosaccharides are not affected by pasteurization and freeze-drying. J. Matern.-Fetal Neonatal Med. 2019, 32, 985-991. [CrossRef]

58. Silva, F.F.; Gloria, B.A. Effect of pasteurization on bioactive amines in human milk. In Proceedings of the 11th International Congress on Engineering and Food, Athens, Greece, 22-26 May 2011; Volume 3, pp. 1781-1783.

59. Van Der Voorn, B.; De Waard, M.; Dijkstra, L.R.; Heijboer, A.C.; Rotteveel, J.; Van Goudoever, J.B.; Finken, M.J. Stability of cortisol and cortisone in human breast milk during holder pasteurization. J. Pediatric Gastroenterol. Nutr. 2017, 65, 658-660. [CrossRef] [PubMed]

60. Ley, S.H.; Hanley, A.J.; Stone, D.; O'connor, D.L. Effects of pasteurization on adiponectin and insulin concentrations in donor human milk. Pediatric Res. 2011, 70, 278. [CrossRef]

61. Resto, M.; O'Connor, D.; Leef, K.; Funanage, V.; Spear, M.; Locke, R. Leptin levels in preterm human breast milk and infant formula. Pediatrics 2001, 108, e15. [CrossRef]

62. Ewaschuk, J.B.; Unger, S.; Harvey, S.; O'Connor, D.L.; Field, C.J. Effect of pasteurization on immune components of milk: Implications for feeding preterm infants. Appl. Physiol. Nutr. MeTable 2011, 36, 175-182. [CrossRef]

63. Moltó-Puigmartí, C.; Permanyer, M.; Castellote, A.I.; López-Sabater, M.C. Effects of pasteurisation and high-pressure processing on vitamin C, tocopherols and fatty acids in mature human milk. Food Chem. 2011, 124, 697-702. [CrossRef] 
64. Fidler, N.; Sauerwald, T.U.; Demmelmair, H.; Koletzko, B. Fat content and fatty acid composition of fresh, pasteurized, or sterilized human milk. In Bioactive Components of Human Milk; Springer: Boston, MA, USA, 2001; pp. 485-495.

65. Henderson, T.R.; Fay, T.N.; Hamosh, M. Effect of pasteurization on long chain polyunsaturated fatty acid levels and enzyme activities of human milk. J. Pediatrics 1998, 132, 876-878. [CrossRef]

66. Israel-Ballard, K.; Coutsoudis, A.; Chantry, C.; Sturm, A.; Karim, F.; Sibeko, L.; Abrams, B. Bacterial safety of flash-heated and unheated expressed breastmilk during storage. J. Trop. Pediatrics 2006, 52, 399-405. [CrossRef]

67. Van Zoeren-Grobben, D.; Schrijver, J.; Van den Berg, H.; Berger, H. Human milk vitamin content after pasteurisation, storage, or tube feeding. Arch. Dis. Child. 1987, 62, 161-165. [CrossRef] [PubMed]

68. Ribeiro, K.D.; Melo, I.L.; Pristo, A.Z.; Dimenstein, R. The effect of processing on the vitamin A content of human milk. J. Pediatr. 2005, 81, 61-64. [CrossRef]

69. Ford, J.; Law, B.; Marshall, V.M.; Reiter, B. Influence of the heat treatment of human milk on some of its protective constituents. J. Pediatrics 1977, 90, 29-35. [CrossRef]

70. Rodríguez-Camejo, C.; Puyol, A.; Fazio, L.; Rodríguez, A.; Villamil, E.; Andina, E.; Cordobez, V.; Díaz, H.; Lemos, M.; Siré, G. Antibody profile of colostrum and the effect of processing in human milk banks: Implications in immunoregulatory properties. J. Hum. Lact. 2018, 34, 137-147. [CrossRef]

71. Cossey, V.; Jeurissen, A.; Bossuyt, X.; Schuermans, A. Effect of pasteurisation on the mannose-binding lectin activity and the concentration of soluble CD14 in human milk. J. Hosp. Infect. 2009, 73, 96-97. [CrossRef] [PubMed]

72. McPherson, R.J.; Wagner, C.L. The effect of pasteurization on transforming growth factor alpha and transforming growth factor beta 2 concentrations in human milk. In Bioactive Components of Human Milk; Springer: Boston, MA, USA, 2001; pp. 559-566.

73. Untalan, P.B.; Keeney, S.E.; Palkowetz, K.H.; Rivera, A.; Goldman, A.S. Heat susceptibility of interleukin-10 and other cytokines in donor human milk. Breastfeed. Med. 2009, 4, 137-144. [CrossRef]

74. Franch, A.; Audí, C.; Ramírez-Santana, C.; Permanyer, M.; Pérez-Cano, F.; Moltó-Puigmartí, C.; López-Sabater, M.; Castellote, C. Banked human milk treatment and immunoactive factors content. Comparison with high pressure processing. Proc. Nutr. Soc. 2010, 69, E288. [CrossRef]

75. Mateos-Vivas, M.; Rodríguez-Gonzalo, E.; Domínguez-Álvarez, J.; García-Gómez, D.; Ramírez-Bernabé, R.; Carabias-Martínez, R. Analysis of free nucleotide monophosphates in human milk and effect of pasteurisation or high-pressure processing on their contents by capillary electrophoresis coupled to mass spectrometry. Food Chem. 2015, 174, 348-355. [CrossRef]

76. Contador, R.; Delgado, F.; García-Parra, J.; Garrido, M.; Ramírez, R. Volatile profile of breast milk subjected to high-pressure processing or thermal treatment. Food Chem. 2015, 180, 17-24. [CrossRef]

77. Delgado, F.J.; Contador, R.; Álvarez-Barrientos, A.; Cava, R.; Delgado-Adámez, J.; Ramírez, R. Effect of high pressure thermal processing on some essential nutrients and immunological components present in breast milk. Innov. Food Sci. Emerg. Technol. 2013, 19, 50-56. [CrossRef]

78. Delgado, F.J.; Cava, R.; Delgado, J.; Ramírez, R. Tocopherols, fatty acids and cytokines content of holder pasteurised and high-pressure processed human milk. Dairy Sci. Technol. 2014, 94, 145-156. [CrossRef]

79. Peila, C.; Moro, G.E.; Bertino, E.; Cavallarin, L.; Giribaldi, M.; Giuliani, F.; Cresi, F.; Coscia, A. The effect of holder pasteurization on nutrients and biologically-active components in donor human milk: A review. Nutrients 2016, 8, 477. [CrossRef]

80. Vieira, A.A.; Soares, F.V.M.; Pimenta, H.P.; Abranches, A.D.; Moreira, M.E.L. Analysis of the influence of pasteurization, freezing/thawing, and offer processes on human milk's macronutrient concentrations. Early Hum. Dev. 2011, 87, 577-580. [CrossRef] [PubMed]

81. Parra-Llorca, A.; Gormaz, M.; Alcántara, C.; Cernada, M.; Nuñez-Ramiro, A.; Vento, M.; Collado, M.C. Preterm Gut Microbiome Depending on Feeding Type: Significance of Donor Human Milk. Front. Microbiol. 2018, 9, 1376. [CrossRef] [PubMed]

82. Schlotterer, H.R.; Perrin, M.T. Effects of Refrigerated and Frozen Storage on Holder-Pasteurized Donor Human Milk: A Systematic Review. Breastfeed. Med. 2018, 13, 465-472. [CrossRef]

83. Villamor-Martínez, E.; Pierro, M.; Cavallaro, G.; Mosca, F.; Kramer, B.; Villamor, E. Donor human milk protects against bronchopulmonary dysplasia: A systematic review and meta-analysis. Nutrients 2018, 10, 238. [CrossRef] 
84. Corpeleijn, W.E.; De Waard, M.; Christmann, V.; van Goudoever, J.B.; Jansen-van der Weide, M.C.; Kooi, E.M.; Koper, J.F.; Kouwenhoven, S.M.; Lafeber, H.N.; Mank, E. Effect of donor milk on severe infections and mortality in very low-birth-weight infants: The early nutrition study randomized clinical trial. JAMA Pediatrics 2016, 170, 654-661. [CrossRef]

85. O'Connor, D.L.; Gibbins, S.; Kiss, A.; Bando, N.; Brennan-Donnan, J.; Ng, E.; Campbell, D.M.; Vaz, S.; Fusch, C.; Asztalos, E. Effect of supplemental donor human milk compared with preterm formula on neurodevelopment of very low-birth-weight infants at 18 months: A randomized clinical trial. JAMA 2016, 316, 1897-1905. [CrossRef]

86. Quigley, M.; McGuire, W. Formula versus donor breast milk for feeding preterm or low birth weight infants. Cochrane Database Syst. Rev. 2014. [CrossRef]

87. Silano, M.; Milani, G.P.; Fattore, G.; Agostoni, C. Donor human milk and risk of surgical necrotizing enterocolitis: A meta-analysis. Clin. Nutr. 2019, 38, 1061-1066. [CrossRef] [PubMed]

88. Moro, G.E.; Billeaud, C.; Rachel, B.; Calvo, J.; Cavallarin, L.; Christen, L.; Escuder-Vieco, D.; Gaya, A.; Lembo, D.; Wesolowska, A. Processing of Donor Human Milk: Update and Recommendations from the European Milk Bank Association (EMBA). Front. Pediatrics 2019, 7, 49. [CrossRef] [PubMed]

(C) 2019 by the authors. Licensee MDPI, Basel, Switzerland. This article is an open access article distributed under the terms and conditions of the Creative Commons Attribution (CC BY) license (http://creativecommons.org/licenses/by/4.0/). 